\title{
Obliczanie inwersji sejsmicznej na azymutalnych transformacjach PPS-WPG fal podłużnych i poprzecznych
}

\begin{abstract}
W artykule przedstawiono wyniki obliczeń inwersji sejsmicznej wykonywanej na azymutalnych transformacjach PPS-WPG fal podłużnych PP i poprzecznych PS. Realizacja przedmiotowego zadania była prowadzona na zarejestrowanych wieloazymutalnych pomiarach PPS 3C, pochodzących z północnego obszaru Polski. Otrzymane rezultaty użycia inwersji sejsmicznej, obliczanej metodą rekursywną, na transformacjach PPS-WPG wskazują, że metoda ta daje zadowalające wyniki do wyznaczania rozkładu zmienności prędkości akustycznych i gęstości w strefie okołootworowej.
\end{abstract}

Słowa kluczowe: PPS, transformacja PPS-WPG, inwersja sejsmiczna, fale podłużne, fale poprzeczne.

\section{Calculation of seismic inversion on VSP-CDP azimuthal transformations of longitudinal and transverse waves}

This article presents results of seismic inversion calculation, on VSP-CDP azimuthal transformations for longitudinal PP and transverse PS waves. Implementation of this task was performed on recorded VSP 3C multi-azimuthal measurements from northern Poland. The results of seismic inversion, calculated by recursive method on VSP-CDP transformations, indicate that this method provides satisfactory results for the determination of variability acoustic velocity and density distribution in a wellbore zone.

Key words: VSP, VSP-CDP transform, seismic inversion, longitudinal waves, transverse waves.

\section{Wstęp}

Precyzyjne określenie zmian parametrów sprężystych w strefie okołootworowej umożliwia poprawne rozpoznanie właściwości geomechanicznych ośrodka geologicznego oraz wyznaczenie rozkładu parametrów złożowych w sąsiedztwie odwiertu badawczego. Stopień dokładności rozpoznania parametrów sprężystych strefy złożowej ośrodka geologicznego wokół otworu oraz poprawna identyfikacja kierunków migracji węglowodorów w istotnym stopniu rzutują na efektywność eksploatacji węglowodorów oraz na dokładność wierceń otworów poziomych lub kierunkowych.

Użycie technologii pomiarów PPS 3C typu wieloazymutalnego w badaniach sejsmicznych daje unikalną możliwość kierunkowej identyfikacji parametrów sprężystych na transformacjach PPS-WPG. Zastosowanie inwersji sejsmicznej, obliczanej metodą deterministyczną lub probabilistyczną (stochastyczną), na transformacjach PPS-WPG fal podłużnych PP i poprzecznych PS umożliwia uzyskanie rozkładu prędkości i gęstości, które stanowią podstawę do szczegółowego śledzenia zmian parametrów złożowych ośrodka geologicznego w strefie okołootworowej. Ponadto analizy okołootworowe na podstawie wieloazymutalnych pomiarów PPS 3C mogą być istotnie pomocne w określeniu dystrybucji szczelin i ich intensywności wokół otworu.

W świetle aktualnych poszukiwań naftowych, prowadzonych w złożach niekonwencjonalnych typu shale gas, shale oil oraz tight gas, precyzyjna identyfikacja parametrów geologiczno-złożowych jest bardzo istotna, gdyż znacząco wpływa na rentowność eksploatacji, zmniejszając ryzyko inwestycji. 


\section{Wieloazymutalne pomiary PPS 3C}

Metoda pomiarów pionowego profilowania sejsmicznego PPS w wersji oddalonej (offset) dla różnych azymutów, przy użyciu sond wieloskładnikowych 3C (PPS 3C), jest najbardziej przydatną z metod sejsmicznych w badaniu zmienności parametrów fizycznych ośrodka geologicznego. Azymutalne i wieloskładnikowe pomiary pionowego profilowania sejsmicznego PPS 3C stanowią najbardziej użyteczne narzędzie spośród aktualnych metod sejsmicznych do badania anizotropii przestrzeni geologicznej (rysunek 1). Generowane na powierzchni fale sprężyste są odbierane przez sondy wieloskładnikowe znajdujące się w otworze, co umożliwia obserwację zmian pola falowego in situ [2, 4, 7].

Pomiary PPS 3C dla różnych azymutów pozwalają na dokładną obserwację zmian amplitud i dynamiki pola falowego fal podłużnych $\mathrm{P}$ oraz poprzecznych S w strefie okołootworowej. Obliczone prędkości interwałowe z czasów pierwszych wstąpień fal podłużnych i poprzecznych są podstawą do szacowania ilościowej anizotropii oraz badania kierunkowej zmienności parametrów sprężystych w okołootworowej przestrzeni geologicznej [1].

Rejestracja pola falowego w metodzie PPS 3C, w zależności od warunków akwizycji oraz zastosowanej technologii pomiarowej, pozwala otrzymywać wyniki charakteryzujące się różną jakością zapisu. W zarejestrowanych danych rzeczywistych PPS 3C obserwuje się zapis fal użytecznych - padających (downgoing waves), charakteryzujących się wysokoamplitudowym zapisem pierwszych wstąpien, oraz następujących po nich fal padających wielokrotnych (downgoing multiples), powstających na różnych głębokościach ośrodka geologicznego. Ponadto występują fale odbite jednokrotne (upgoing waves) i następujące po nich fale odbite wielokrotne (upgoing multiples), o znacznie słabszej amplitudzie. W przypadku rejestracji PPS $3 \mathrm{C}$ dodatkowo obserwujemy fale poprzeczne - konwertowane. Wraz z rejestracją fal użytecznych w zapisie sejsmicznym rejestruje się wiele zakłóceń,

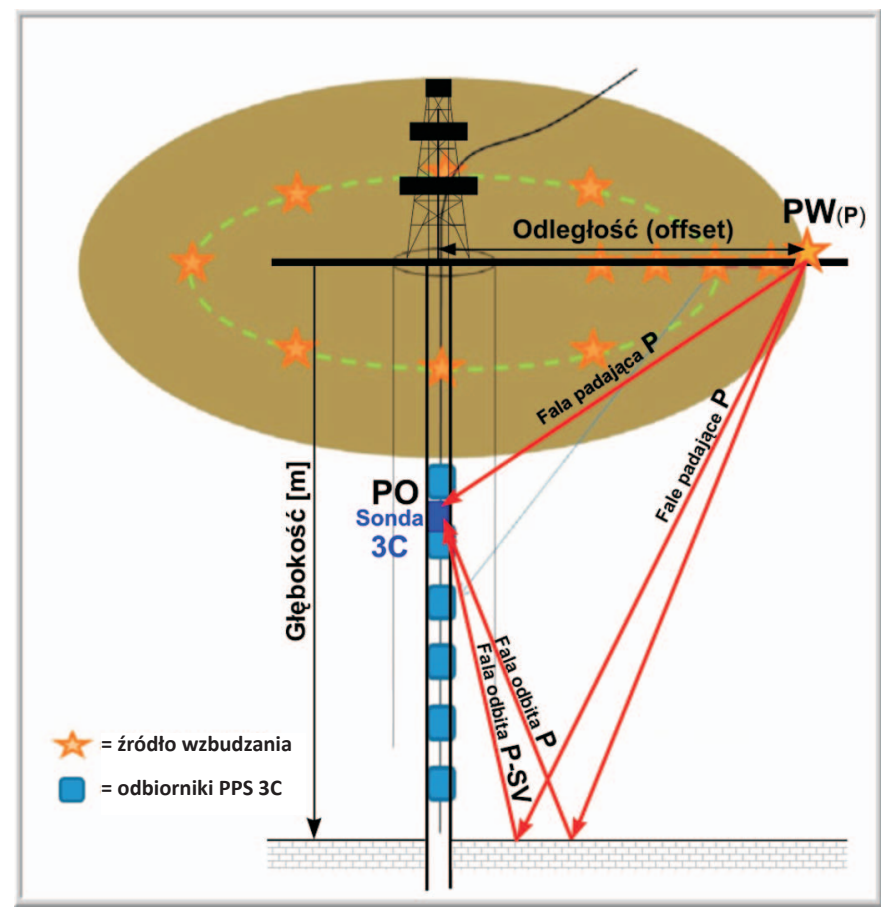

Rys. 1. Schemat azymutalnego układu pomiarowego w metodzie PPS 3C (multi-offset VSP) wraz z uwzględnieniem geometrii propagacji fal sejsmicznych

zarówno koherentnych, jak i przypadkowych, pochodzących m.in. od aparatury pomiarowej, kolumny rur z płynami złożowymi, strefy przypowierzchniowej, aktywności cywilizacyjnej, które w dużym stopniu wpływają na wielkość S/N [3].

Zasadniczym celem przetwarzania PPS jest usunięcie wszelkich możliwych zakłóceń, które zniekształcają rzeczywisty obraz fal użytecznych (padających, odbitych), a następnie wykonanie selekcji i eliminacji określonych typów fal, wzmocnienie i zwiększenie rozdzielczości pola fal odbitych, a w efekcie końcowym - przygotowanie wyników PPS w postaci m.in. trasy sumarycznej, transformacji PPS-WPG, modelu prędkości fal PP i PS do korelacji z danymi sejsmiki powierzchniowej i geofizyki otworowej $[5,11]$.

\section{Inwersja sejsmiczna}

Odtworzenie parametrów ośrodka na podstawie zarejestrowanego obrazu falowego sejsmiki powierzchniowej jest zagadnieniem odwrotnym. Procedury umożliwiające odtworzenie prędkości z danych sejsmicznych noszą nazwę inwersji sejsmicznej.

Inwersja sejsmiczna jest cennym narzędziem geofizycznym pozwalającym na estymację parametrów fizycznych ośrodka geologicznego z danych sejsmicznych w postaci zmian impedancji, będącej iloczynem gęstości i prędkości propagacji. Inwersja sejsmiczna umożliwia przekształcenie amplitudy refleksów sejsmicznych w fizyczne parametry skał i w konsekwencji ilościowy opis złoża. W uproszczonej formie można ją rozumieć jako wyznaczenie otworowej impedancji akustycznej dla każdej trasy sekcji sejsmicznej. Jest ona podstawową procedurą odtworzenia prędkości sejsmicznych [6,9].

Z uwagi na sposób obliczania inwersji sejsmicznej wyróżnia się dwie metody: deterministyczną oraz probabilistyczną. Obie mogą być zastosowane dla danych sejsmicznych zarówno po składaniu (post-stack), jak i przed składaniem (pre-stack). Inwersja sejsmiczna realizowana na 
danych sejsmicznych po składaniu uniemożliwia uzyskanie informacji o prędkościach propagacji fali poprzecznej. Ograniczenia te eliminuje inwersja na rekordach pojedynczych tras sejsmicznych przed składaniem, wykorzystująca zależność współczynnika odbicia od kąta padania (a tym samym od odległości), określoną równaniem Zoeppritza [10].

Wyznaczanie rozkładu prędkości na transformacjach PPS-WPG dla fal podłużnych i poprzecznych w niniejszym opracowaniu było realizowane za pomocą inwersji sejsmicznej obliczanej metodą deterministyczną (inwersja rekursywna).

Inwersja rekursywna (recursive inversion) oparta jest na klasycznym modelu dekonwolucji. Impedancja w każdej warstwie zostaje wyliczona na podstawie wartości impedancji w warstwie wyższej. Procedura obliczania impedancji opartej na formule rekursywnej wygląda następująco:

$$
Z_{i+1}=Z_{i}\left(\frac{1+C_{i}}{1-C_{i}}\right)=Z_{0} \prod_{j=0}^{i}\left(\frac{1+C_{i}}{1-C_{i}}\right)
$$

gdzie:

$Z_{i}$ - impedancja $i$-tej warstwy (poprzedniej),

$Z_{i+1}$-impedancja $i+1$ warstwy (następnej),

$Z_{0}$-impedancja warstwy pierwszej (startowej),

$C_{i}$ - współczynnik odbicia pomiędzy warstwami $i$-tą i następną $(i+1)$.

Wyniki inwersji posiadają takie samo pasmo częstotliwości jak wejściowe dane sejsmiczne, niższe częstotliwości mogą zostać dodane z modelu początkowego. Parametrem znacząco wpływającym na właściwe odwzorowanie impedancji jest współczynnik skalowania tras sejsmicznych.

\section{Metodyka badań PPS 3C}

Pomiary geofizyczne, sejsmiki otworowej i powierzchniowej zostały wykonane na obszarze znajdującym się na północy Polski. Na podstawie odwiertu W-1 określono profil litostratygraficzny, który reprezentowany jest przez utwory podłoża kambru, ordowiku, syluru, cechsztynu, triasu, jury, kredy oraz kenozoiku.

Jednym z istotnych celów badawczych powyższych prac było rozpoznanie budowy strukturalnej utworów syluru i ordowiku oraz wyznaczenie parametrów geomechanicznych i powiązanie ich z parametrami złoża shale gas dla tych utworów.

Rys. 2. Geometria rozmieszczenia

punktów wzbudzań PPS 3C w otworze W-1

PW-1

$L=1363 \mathrm{~m}$

$\mathrm{A} z=3,5^{\circ}$

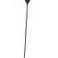

Azymutalne pomiary pionowego profilowania sejsmicznego PPS 3C zostały wykonane w otworze W-1, zlokalizowanym w północnej części Polski, przez Zespół Sejsmiki Otworowej 1D/T Geofizyki Torun w 2011 roku. Źródłem wzbudzania był wibrator MARK III, o zakresie częstotliwości sweepu $8 \div 100 \mathrm{~Hz}$.

W otworze $\mathrm{W}-1$ przeprowadzono cztery pomiary PPS 3C (rysunek 2, tablica 1):

- PW-1, PW-2 i PW-3 - punkty wzbudzania offsetowe, mierzone w przedziale $45 \div 3045 \mathrm{~m}$, interwał pomiarowy $15 \mathrm{~m}$; - PW-4 - punkt wzbudzania zerooffsetowy, mierzony w przedziale $15 \div 3045 \mathrm{~m}$, interwał pomiarowy $15 \mathrm{~m}$.

Analizując dane wejściowe offsetowe PW-1-PW-3 składowej $Z$ PPS 3C, można zauważyć fale padające podłużne (proste), fale poprzeczne padające oraz boczne (rysunek 3). Ponadto na polu falowym PW-1 i PW-3 dodatkowo wyraźnie zaznacza się fala podłużna odbita.

Warto zaznaczyć, że na odległych rejestracjach offsetowych PW-1-PW-3, na głębokościach $45 \div 1035 \mathrm{~m}$, występuje intensywny harmoniczny szum, który wyraźnie osłabił rejestrację fal użytecznych oraz możliwość dokładnego określenia parametrów polaryzacji. $Z$ tej przyczyny przetwarzanie danych oddalonych (PW-1-PW-3) zostało wykonane w interwale $1035 \div 3045 \mathrm{~m}$ (rysunek 3).

Przetwarzanie pomiarów wieloazymutalnych PPS 3C było wykonywane 
Tablica 1. Geometria i parametry układu pomiarowego PPS 3C w otworze W-1

\begin{tabular}{|c|c|c|c|c|}
\hline $\mathrm{PW}$ & Offset PW & Azymut PW & Zakres pomiaru; sonda & Niwelacja \\
\hline $\mathrm{Nr} 1$ & $1363 \mathrm{~m}$ & $3,5^{\circ}$ & $\mathbf{4 5} \div \mathbf{3 0 4 5} ; \mathbf{3 C}$ & $-15 \mathrm{~m}$ \\
\hline $\mathrm{Nr} 2$ & $1395 \mathrm{~m}$ & $117^{\circ}$ & $\mathbf{4 5} \div \mathbf{3 0 4 5} ; \mathbf{3 C}$ & $-58 \mathrm{~m}$ \\
\hline $\mathrm{Nr} 3$ & $1846 \mathrm{~m}$ & $245^{\circ}$ & $\mathbf{4 5} \div \mathbf{3 0 4 5} ; \mathbf{3 C}$ & $-92 \mathrm{~m}$ \\
\hline $\mathrm{Nr} 4$ & $78 \mathrm{~m}$ & $240^{\circ}$ & $\mathbf{1 5} \div \mathbf{3 0 4 5} ; \mathbf{3 C}$ & $+1,0 \mathrm{~m}$ \\
\hline
\end{tabular}

a)

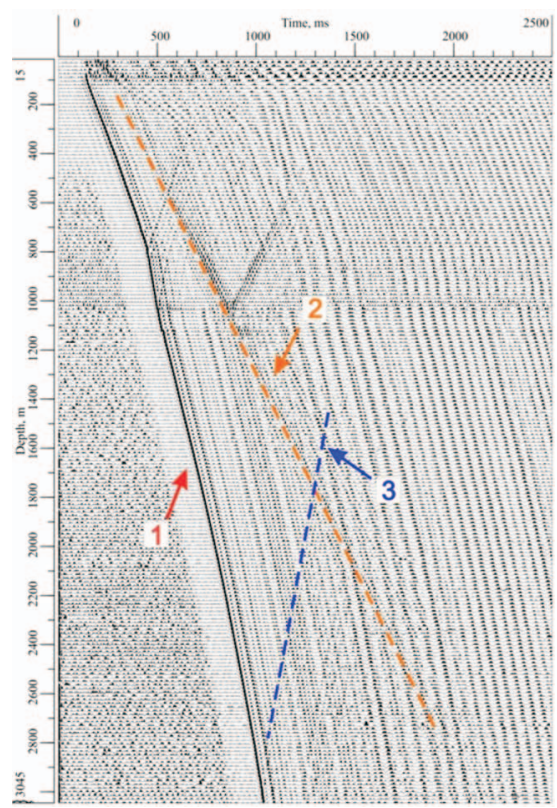

1 - fala padająca prosta, 2 - fala poprzeczna padająca, 3 - fala podłużna odbita b)

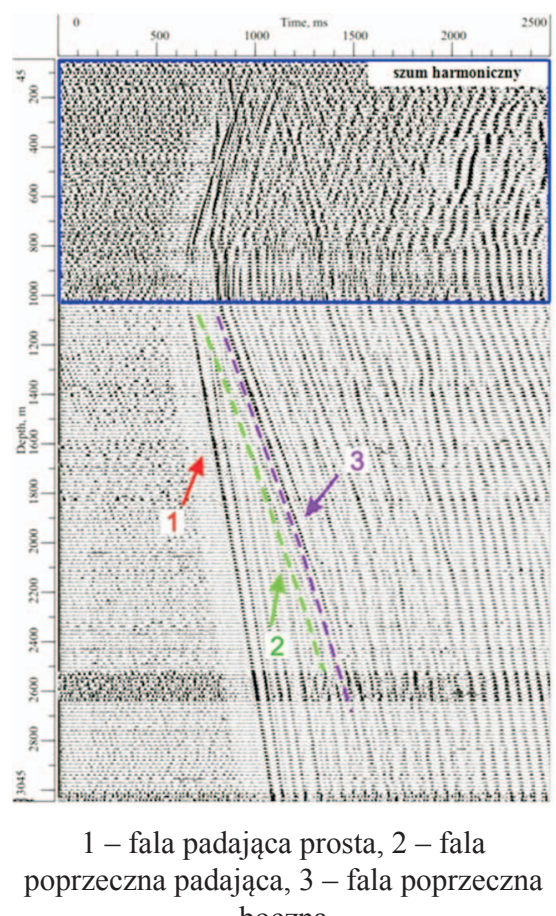

c)

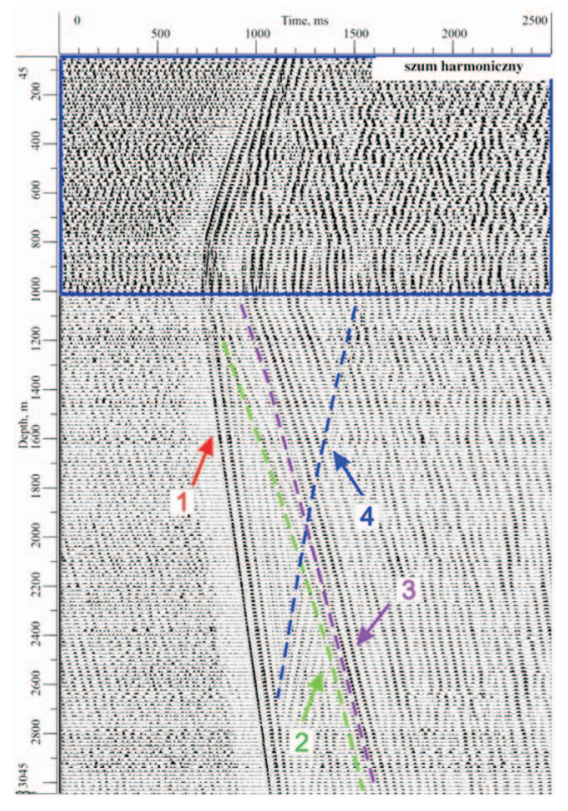

1 - fala padająca prosta, 2 - fala poprzeczna padająca, 3 - fala poprzeczna boczna, 4 - fala podłużna odbita

Rys. 3. Pola wejściowe PPS 3C - składowa pionowa Z; a) punkt wzbudzania PW-1, b) PW-2, c) PW-3

w systemie UNIVERS firmy Geovers Ltd. Moskwa. Wykorzystywano procedury: filtracji minimalno-fazowej i pasmowej, edycji częstotliwościowej tras sejsmicznych, modelowania prędkości, selekcji różnych typów fal i modeli, wprowadzenia poprawek kinematycznych oraz dekonwolucji. Zastosowanie powyższych procedur było niezbędne do uzyskania pól falowych fal podłużnych PP i poprzecznych PS, które zostały użyte do wyznaczenia transformacji PPS-WPG.

\section{Wyznaczanie azymutalnych zmian prędkości na transformacjach PPS-WPG fal PP i PS}

Obliczenie inwersji sejsmicznej w postaci impedancji akustycznej na offsetowych transformacjach PPS-WPG punktów wzbudzań PW-1, PW-2, PW-3 dla fal podłużnych PP i poprzecznych PS było wykonywane na podstawie autorskich programów dr K. Żukowskiej, które obecnie są własnością INiG - PIB. Otrzymane wyniki inwersji sejsmicznej umożliwiły uzyskanie rozkładu prędkości akustycznych i gęstości wzdłuż azymutalnych punktów wzbudzań.

Dla punktu wzbudzania PW-3 fal podłużnych (rysunek 4b) w wynikach impedancji akustycznej można zaobserwować znaczne zgrupowanie wysokich jej wartości i pogorszenie rozdzielczości w przypadku czasów poniżej $800 \mathrm{~ms}, 1100 \mathrm{~ms}$, 1400 ms i 1600 ms. Dla fal poprzecznych PW-3 (rysunek 4d) rozkład impedancji akustycznej jest bardziej rozdzielczy. Powyższe wyniki dla fal podłużnych wskazują na prawdopodobne błędy w obliczeniach, których nie można było zidentyfikować w ich trakcie. Prawdopodobnie jest to efekt procedury inwersji rekursywnej, która uśrednia widmo amplitudowe.

Istotne korzyści przetwarzania fal podłużnych i poprzecznych PPS 3C można zauważyć na rysunku 5. Na obliczone transformacje PPS-WPG dla fal podłużnych (rysunek 5a) i poprzecznych (rysunek 5c) naniesiono stratygrafię i krzywą profilowania akustycznego (PA). Serie złożowe znajdują się w utworach Jantar i Sasino. Na transformacjach PPS-WPG dla fal poprzecznych można dostrzec zdecydowanie lepszą rozdzielczość pionową i poziomą oraz korelację 


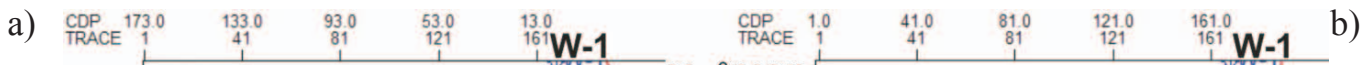
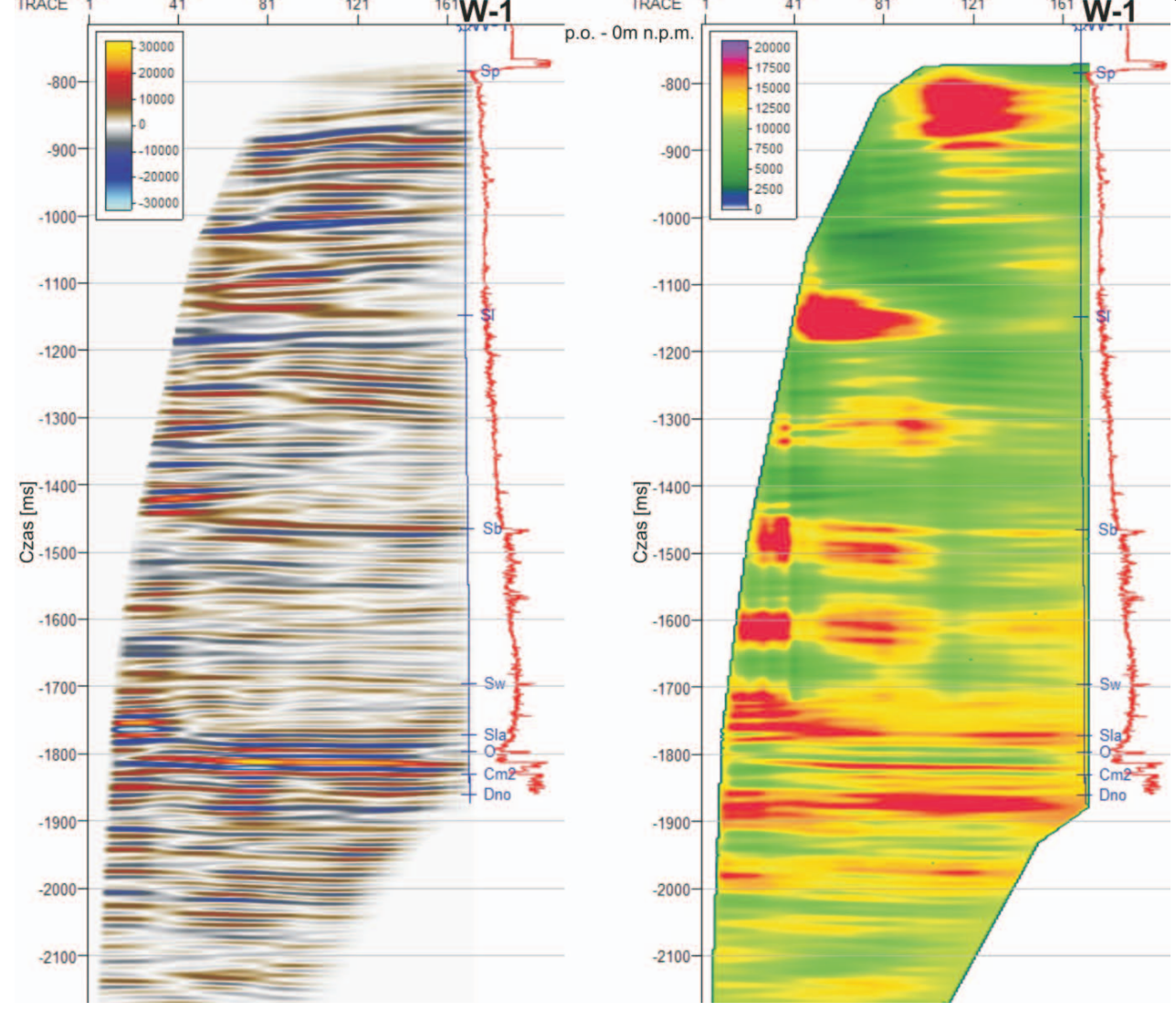

c) $\underset{\mathrm{TRACE}}{\mathrm{COP}}$
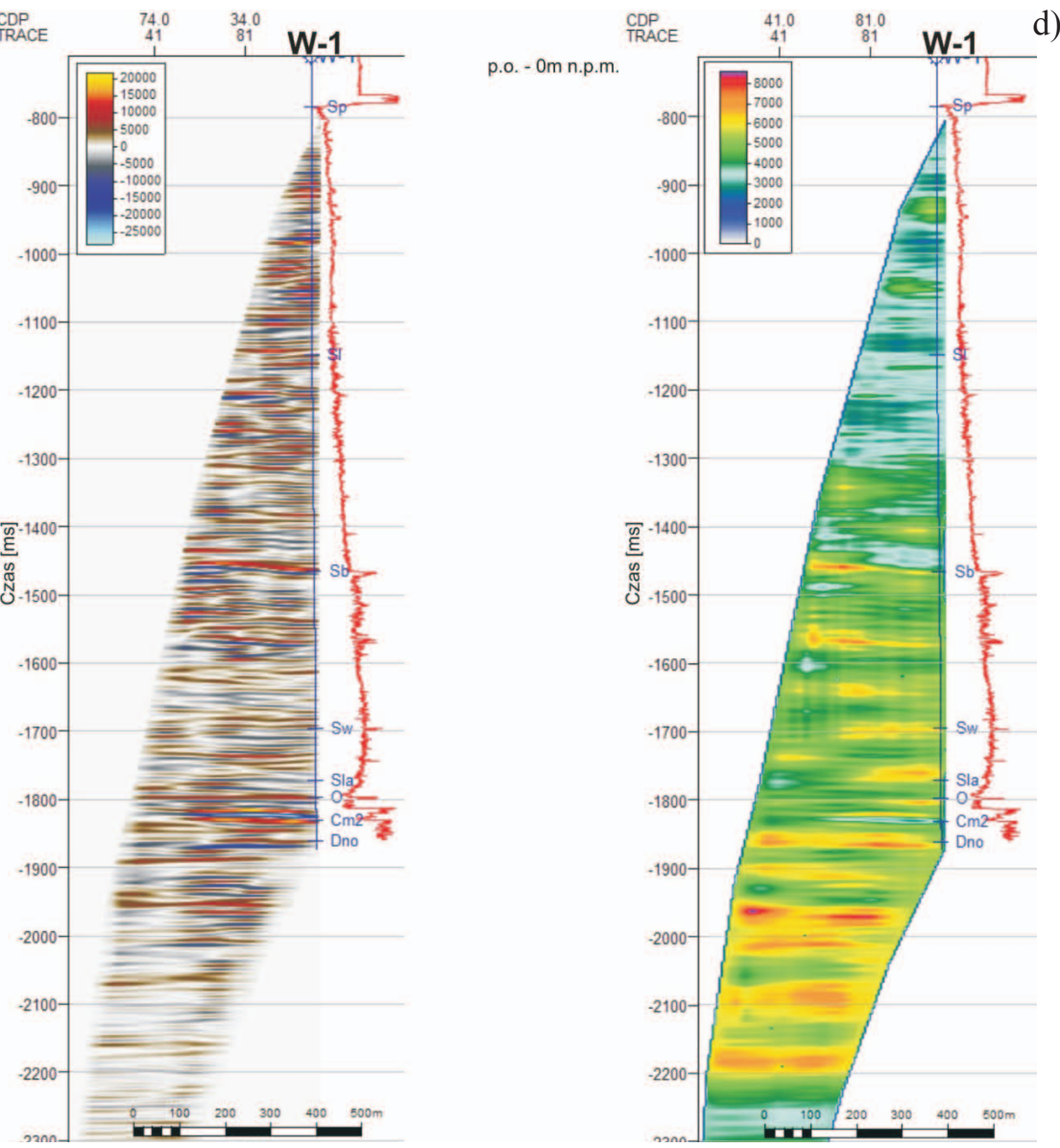

Rys. 4. Zestawienie transformacji PPS-WPG punktu wzbudzania PW-3 dla fal podłużnych - a) pole falowe, b) impedancja akustyczna, oraz poprzecznych - c) pole falowe, d) impedancja akustyczna z dopasowaniem profilowania akustycznego 
a)

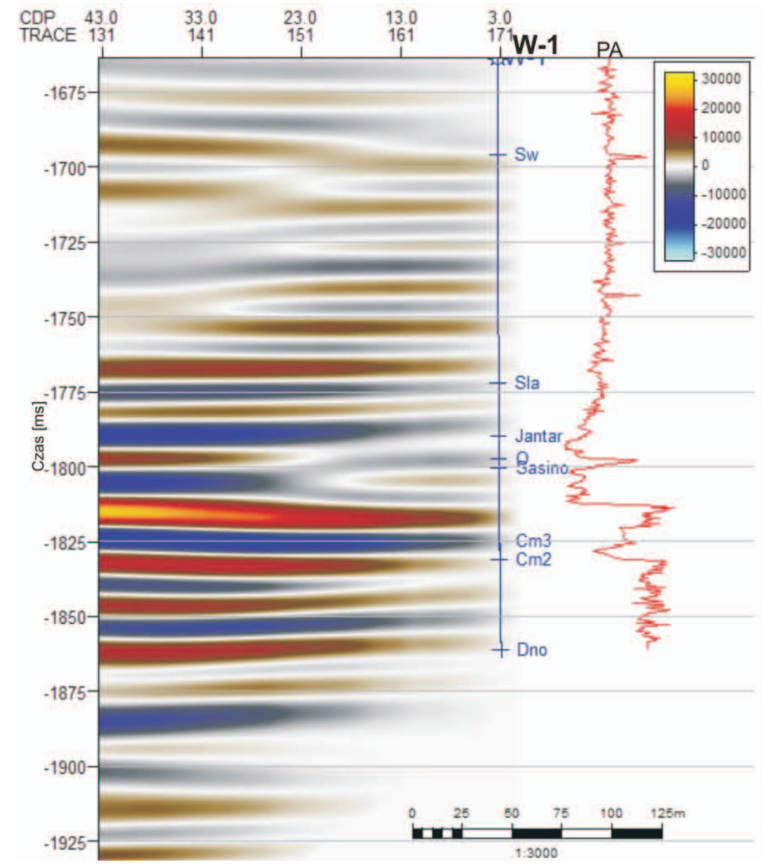

c)

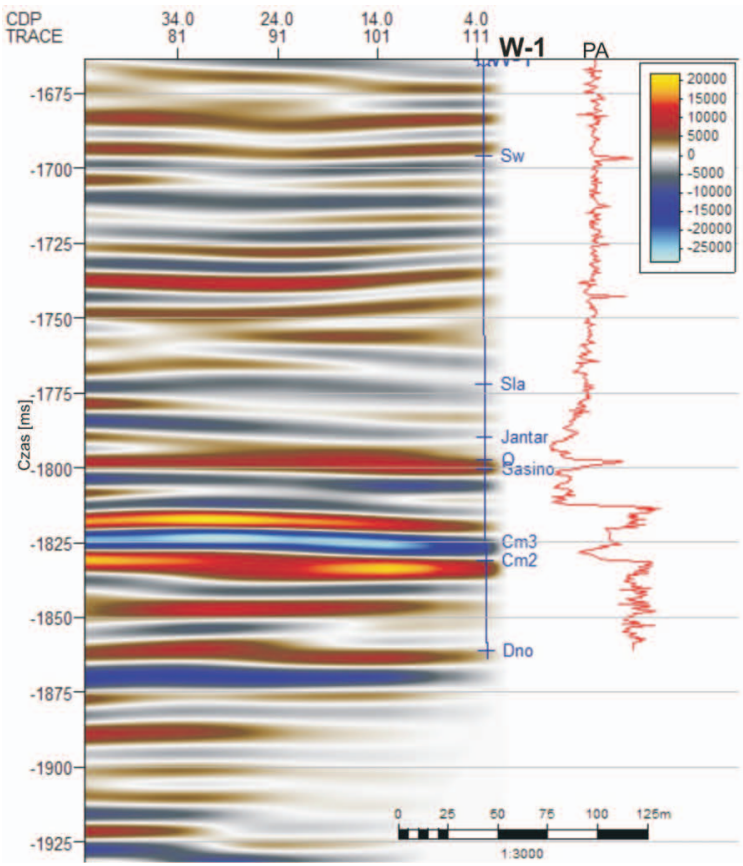

b)

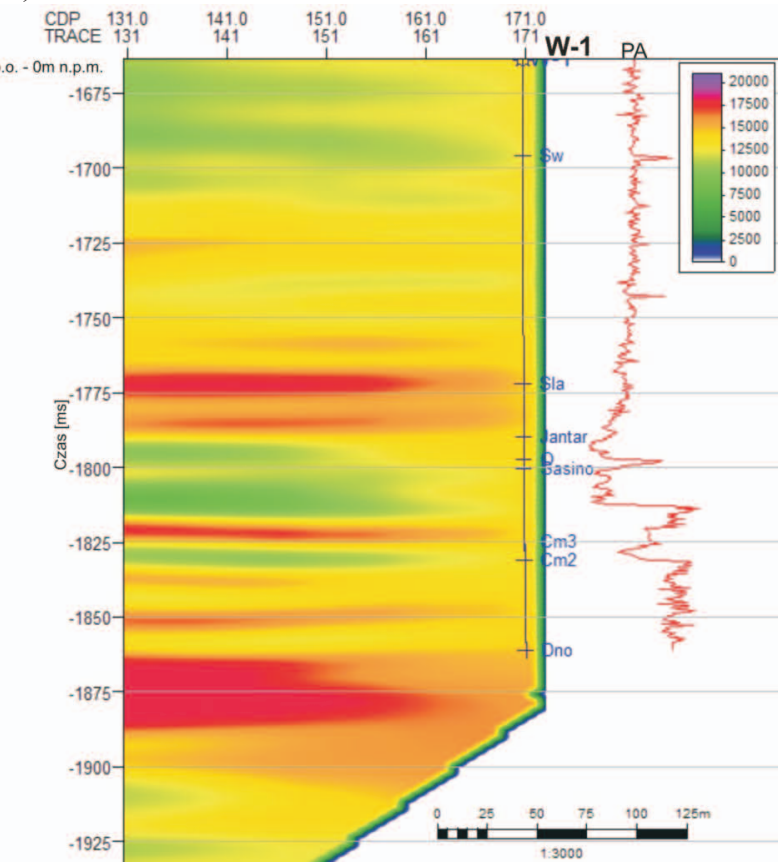

d)

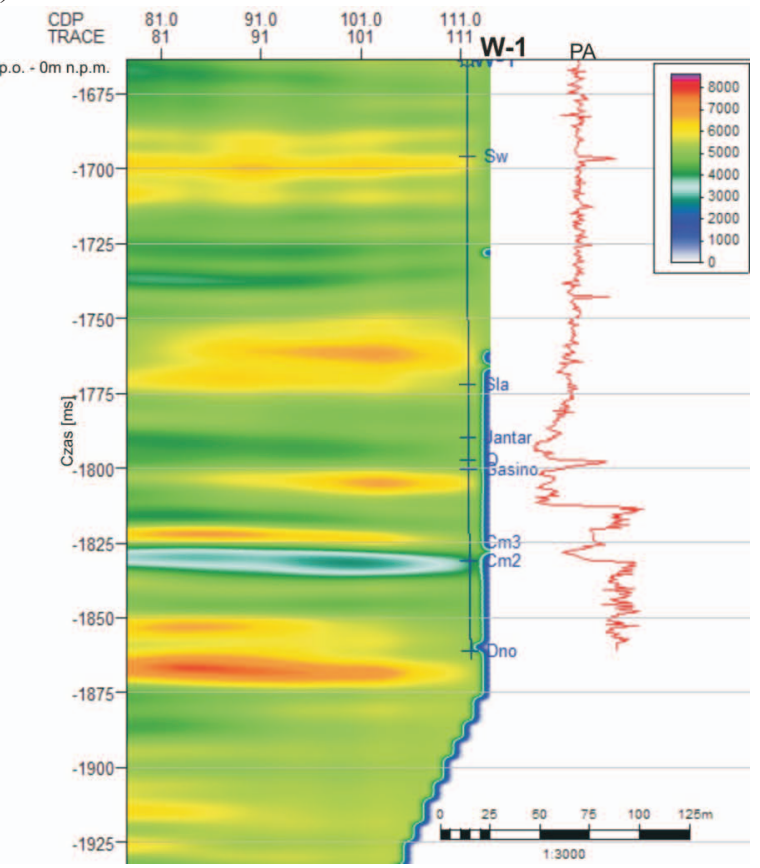

Rys. 5. Zestawienie fragmentów transformacji PPS-WPG punktu wzbudzania PW-3 dla fal podłużnych - a) pole falowe,

b) impedancja akustyczna, oraz poprzecznych - c) pole falowe, d) impedancja akustyczna z dopasowaniem profilowania akustycznego (PA)

stratygraficzną (rysunek 5c, d), natomiast w przypadku fal podłużnych, zwłaszcza w interwale złożowym, tej dokładności się nie dostrzega (rysunek 5a, b).

W pozostałych przykładach obliczeń impedancji akustycznej, prędkości oraz gęstości dla PW-1, PW-2 i PW-3 fal podłużnych i poprzecznych (rysunki 6 i 7) można zauważyć zadowalającą zmienność poziomą i pionową obliczanych parametrów. Uzyskane wyniki mogą być użyte do obliczeń współczynnika $V p / V s$, rozkładu porowatości oraz anomalnych ciśnień, po napisaniu stosownych programów i wdrożeniu ich do prac przemysłowych.

Otrzymane rezultaty zastosowania inwersji sejsmicznej na transformacjach PPS-WPG dla otworu W-1, obliczanej metodą rekursywną, wskazują, że metoda ta daje zadowalające wyniki do interpretacji jakościowej i ilościowej parametrów złożowych.

Warto zaznaczyć, że obliczone prędkości fal podłużnych $(V p)$ i poprzecznych $(V s)$ z danych PPS 3C na różnych 
a)

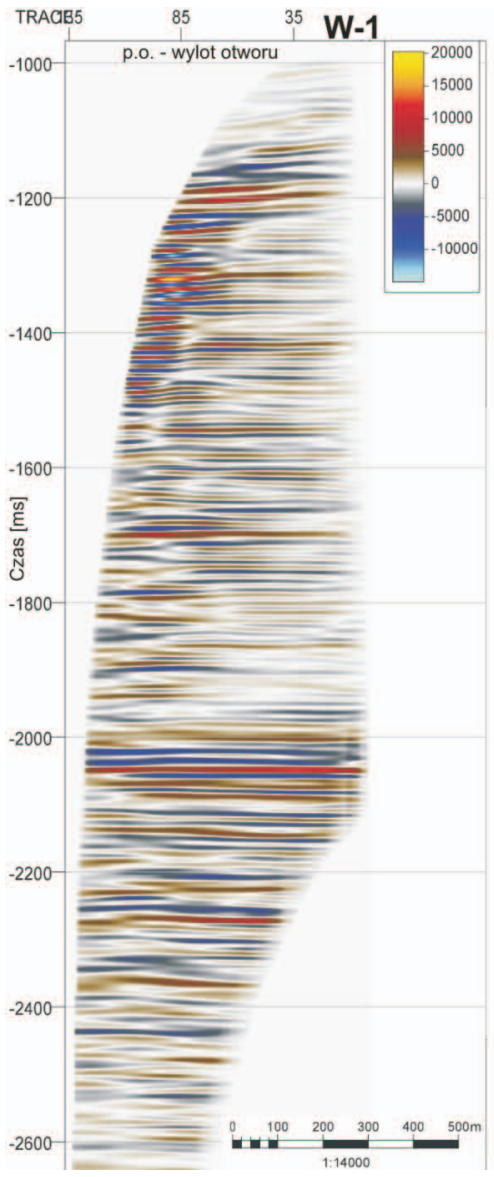

c)

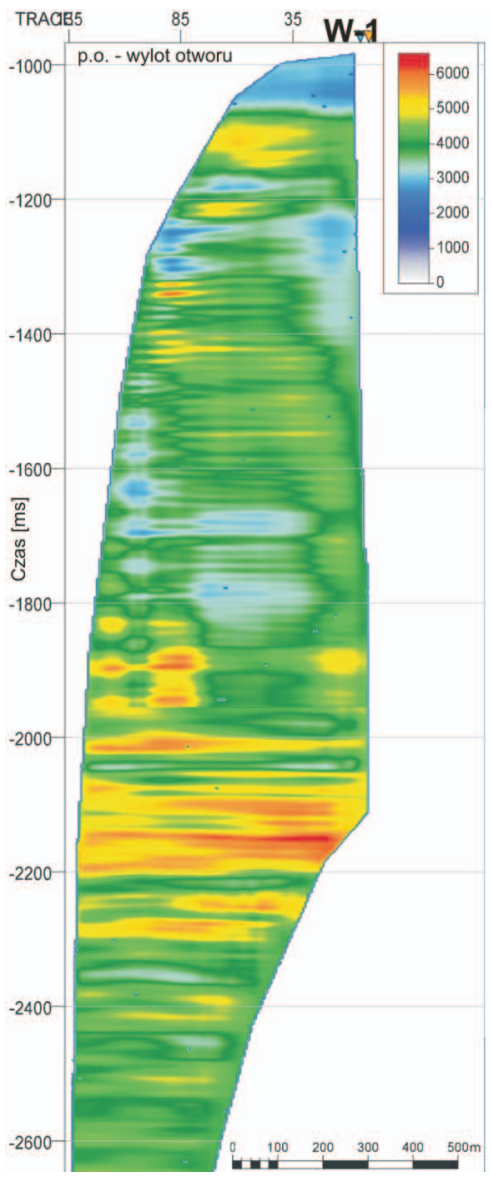

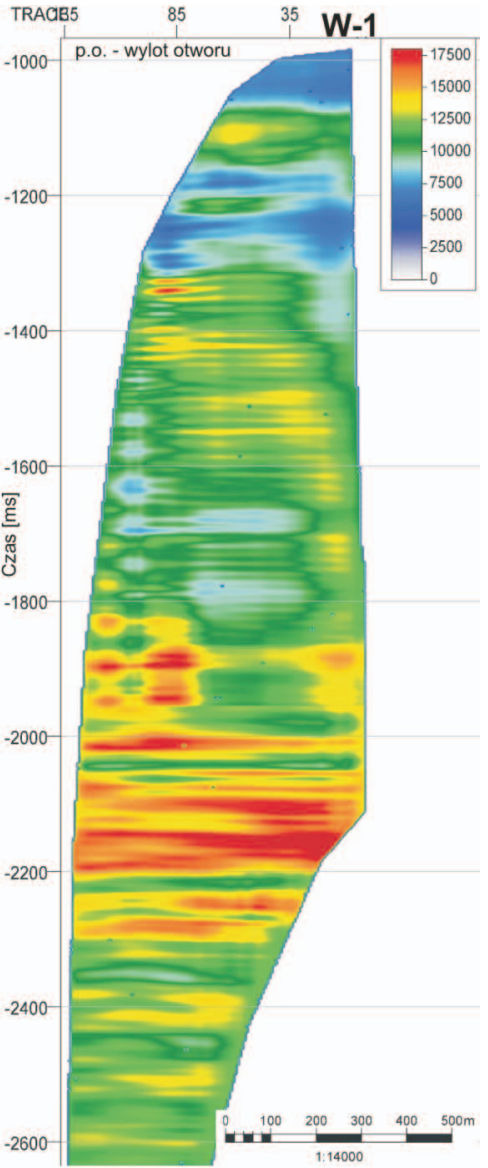
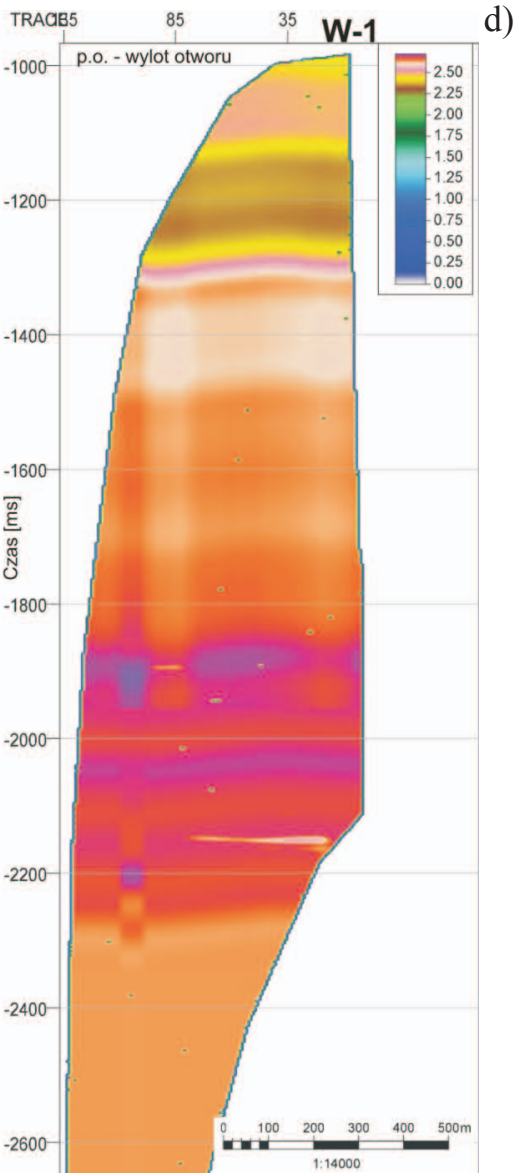

b)

d)

Rys. 6. Zestawienie transformacji PPS-WPG dla fal podłużnych punktu wzbudzania PW-1 - a) pole falowe, b) impedancja akustyczna, c) prędkość akustyczna $[\mathrm{m} / \mathrm{s}]$, d) gęstość $\left[\mathrm{g} / \mathrm{cm}^{3}\right]$ 
a)

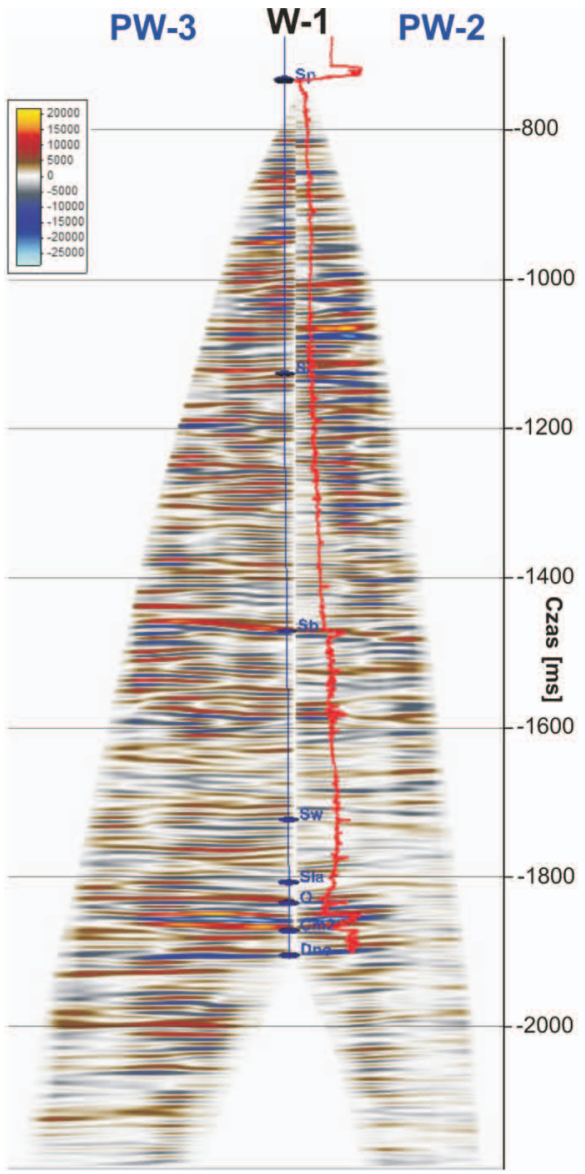

c)

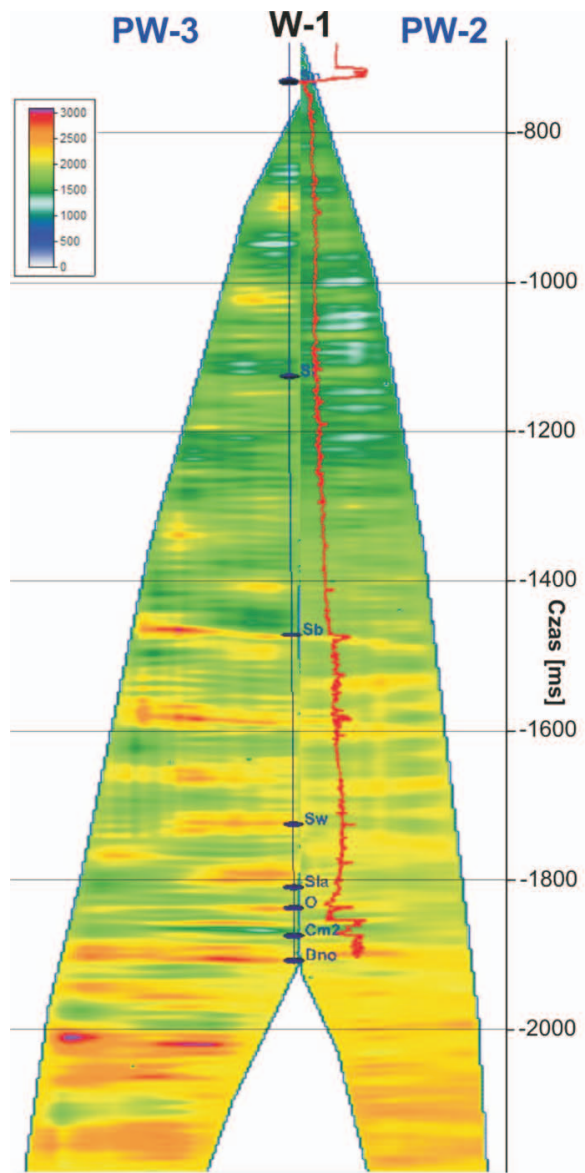

p.o. - 0 m n.p.m

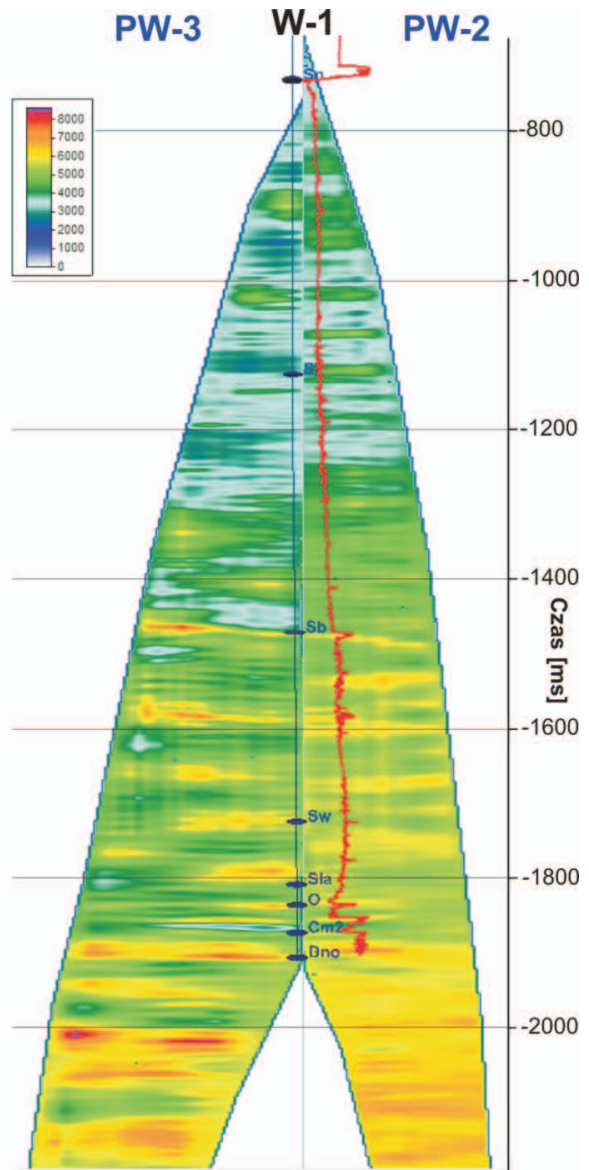

p.o. - Om n.p.m.

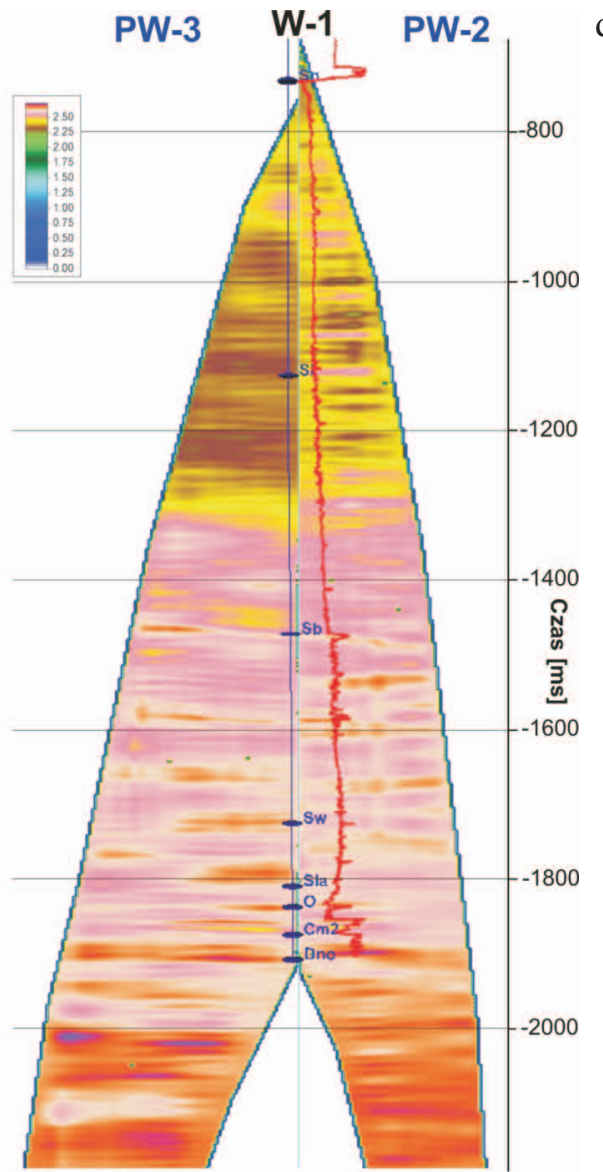

b)

d)

Rys. 7. Korelacyjne zestawienie transformacji PPS-WPG dla fal poprzecznych punktów wzbudzań PW-3 i PW-2 a) pole falowe, b) impedancja akustyczna, c) prędkość akustyczna $[\mathrm{m} / \mathrm{s}]$, d) gęstość $\left[\mathrm{g} / \mathrm{cm}^{3}\right]$ 
azymutach - umożliwiają kierunkową identyfikację facjalną oraz złożową $(V p / V s)$ ośrodka geologicznego. Parametr $(V p / V s)$ może być użyty jako atrybut sejsmiczny opisujący złoża typu tight gas, shale gas czy shale oil. Wyznaczone prędkości podłużne i poprzeczne oraz parametr $(V p / V s)$ mogą być użyte do obliczenia modułu Younga i współczynnika Poissona w celu określenia modelu geomechanicznego ośrodka geologicznego $[5,11]$.

\section{Podsumowanie i wnioski}

Uzyskane wyniki przetwarzania pionowego profilowania sejsmicznego PPS 3C dla otworu W-1 w postaci transformacji PPS-WPG dla fal podłużnych i poprzecznych umożliwiają określenie parametrów złożowych na podstawie obliczonej inwersji sejsmicznej w postaci impedancji akustycznej oraz stanowią podstawę do obliczania parametrów geomechanicznych w przestrzeni okołootworowej.

Rezultaty użycia inwersji sejsmicznej obliczanej metodą rekursywną na transformacjach PPS-WPG wskazują, że metoda ta daje zadowalające wyniki do wyznaczania rozkładu zmienności prędkości akustycznych oraz gęstości.

Prezentowana metodyka dostarcza użytecznych informacji związanych z azymutalnymi zmianami i rozkładem parametrów złożowych oraz zmianami strukturalnymi i litofacjalnymi w przestrzeni geologicznej, które stanowią cenną wiedzę w pracach poszukiwawczych, zwiększając trafność lokalizacji oraz efektywność eksploatacji odwiertów poszukiwawczych.

Autor składa serdeczne podziękowania Dyrekcji Oddziału Geologii i Eksploatacji PGNiG SA za udostępnione materiały sejsmiczne, wykorzystane w niniejszej publikacji. Dodatkowo autor dziękuje dr. A. Tabakovowi za konsultacje udzielone w trakcie przetwarzania azymutalnych pomiarów PPS 3C.

Prosimy cytować jako: Nafta-Gaz 2015, nr 10, s. 711-719.

Artykuł nadesłano do Redakcji 20.11.2014 r. Zatwierdzono do druku 08.04.2015 r.

Artykuł powstał na podstawie pracy statutowej pt. Wyznaczanie parametrów złożowych przy wykorzystaniu azymutalnych pomiarów PPS 3C - praca INiG - PIB na zlecenie MNiSW; nr arch.: DK-4100-0036/14, nr zlecenia: 0036/SR/14.

\section{Literatura}

[1] Barton N.: Fracture-induced seismic anisotropy when sharing is involved in production from fractured reservoirs. Journal of Seismic Exploration 2007, vol. 16, s. 115-143.

[2] Barton R.: Role of VSP measurement in investigation of anisotropy of geological medium. Galperin Readings 2011, Moscow CGE 24-28 October 2011.

[3] Barton R.: Wyznaczanie kierunkowych zmian predkosci fal poprzecznych w strefie okolootworowej na podstawie azymutalnych pomiarow PPS 3C. Nafta-Gaz 2014, nr 8, s. 483-492.

[4] Galperin E. I.: Vertical Seismic Profiling: experience and results. M. Nauka, 1994. ISBN 5-02-002411-2.

[5] Gomez G., Planchart C., Chon Y., Massimo A., Gonzalez G., Sifontes E., Octavio D.: How integration of well log, core, borehole seismic and cross-well seismic data can offer a powerful tool in complex structural situations. First Break 2002, vol. 20, issue 6, s. 404-410.

[6] Gunning J., Glinsky M. E.: Detection of reservoir quality using Bayesian seismic inversion. Geophysics 2007, vol. 72, no. 3, s. R37-R49. DOI: 10.1190/1.2713043.

[7] Hardage B. A.: Vertical Seismic Profiling: Principles. Handbook of Geophysical Exploration: Seismic Exploration, vol. 14. Elsevier Science 2000.

[8] Helland-Hansen D., Magnus I., Edvardsen A., Hansen E.: Seismic Inversion for Reservoir Characterization and Well
Planning in the Snorre Field. The Leading Edge 1997, vol. 16, s. 269-274.

[9] Jedrzejowska-Tyczkowska H., Barton R.: Wspolczesne mozliwosci metody sejsmicznej w zadaniach ilosciowej charakterystyki obiektow zlozowych. Nafta-Gaz 2005, nr 7-8, s. 349-356.

[10] Jedrzejowska-Zwinczak H.: Inwersja sejsmiczna akustyczna i elastyczna fal podluznych, konwertowanych i poprzecznych w zagadnieniach interpretacji zlozowej. Prace Naukowe INiG 2009, nr 160, $85 \mathrm{~s}$.

[11] Walia R., Brandt K., Duthie R., Whittaker R., Malterre E., Bell P.: New concepts for borehole and VSP data integration in seismic data processing. First Break 2005, vol. 23, s. 83-87.

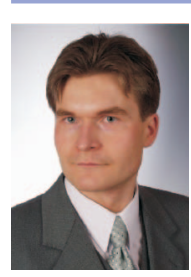

Dr inż. Robert BARTOŃ

Adiunkt w Zakładzie Sejsmiki.

Instytut Nafty i Gazu - Państwowy Instytut Badawczy ul. Lubicz 25 A

31-503 Kraków

E-mail: barton@inig.pl 